Supplement of Atmos. Chem. Phys., 18, 16829-16844, 2018

https://doi.org/10.5194/acp-18-16829-2018-supplement

(c) Author(s) 2018. This work is distributed under

the Creative Commons Attribution 4.0 License.

(c) (i)

Supplement of

\title{
The influence of photochemical aging on light absorption of atmospheric black carbon and aerosol single-scattering albedo
}

Xuezhe Xu et al.

Correspondence to: Weixiong Zhao (wxzhao@aiofm.ac.cn) and Weijun Zhang (wjzhang@aiofm.ac.cn)

The copyright of individual parts of the supplement might differ from the CC BY 4.0 License. 


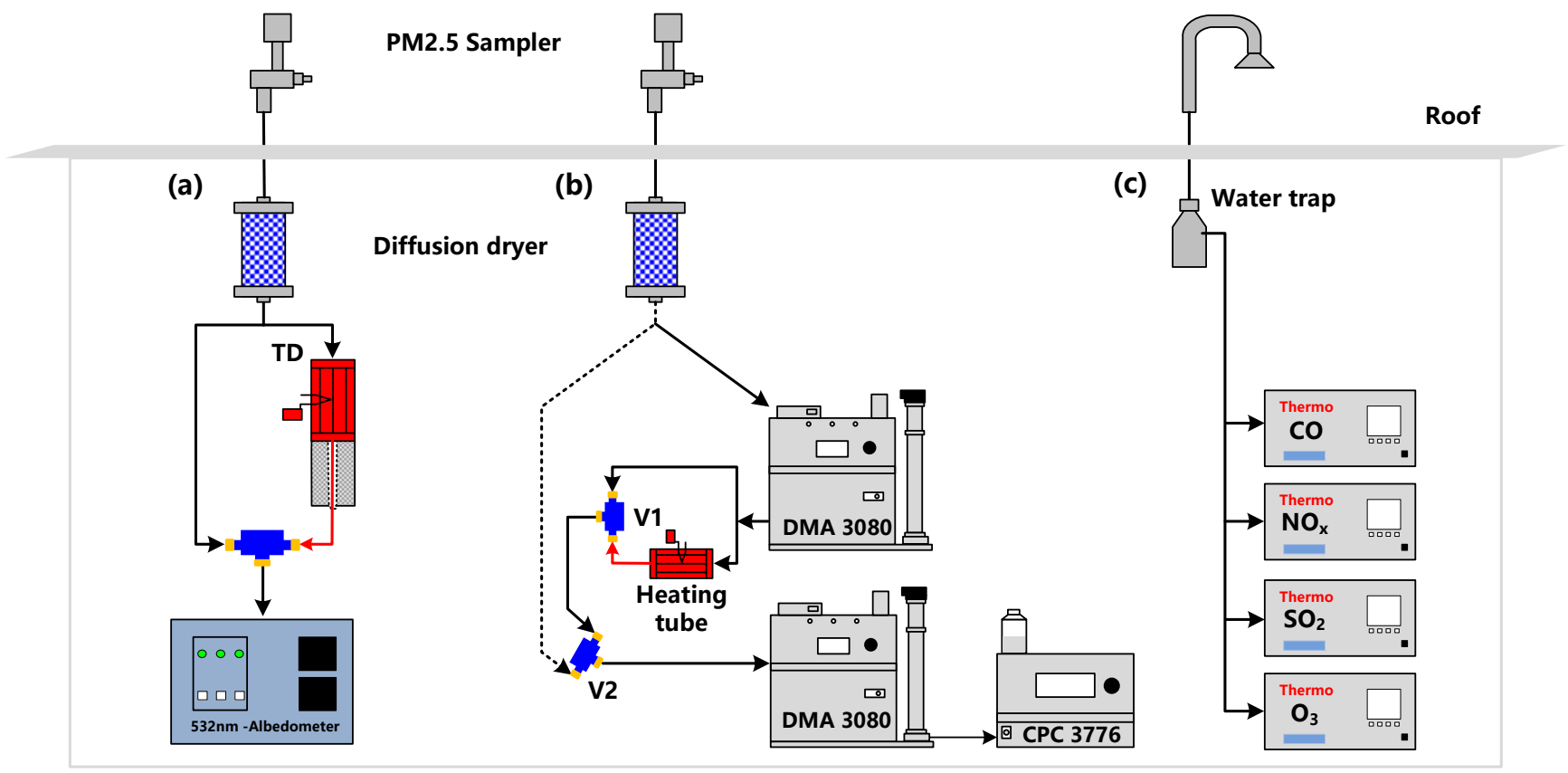

Figure S1: Experimental set-up for the measurements of: (a) aerosol optical properties, (b) volatility of $\mathrm{PM}_{2.5}$ particles, and (c) concentrations of pollutant gases. 


\section{S2 Estimation of the truncation error of the cavity-enhanced albedometer}

The geometry of the cavity-enhanced albedometer is shown in Fig. S2. The inner diameters of the integrating sphere $(L)$ and the truncation reduction tube $(d)$ were $150 \mathrm{~mm}$ and $19 \mathrm{~mm}$, respectively. The length of the sample occupied in the truncation reduction tube $(l)$ was $\sim 197 \mathrm{~mm} . Z$ is the distance of the particle from the scattering location in the sphere to the exit or entrance aperture of the sphere $(Z=0$ is for the centre of the sphere).

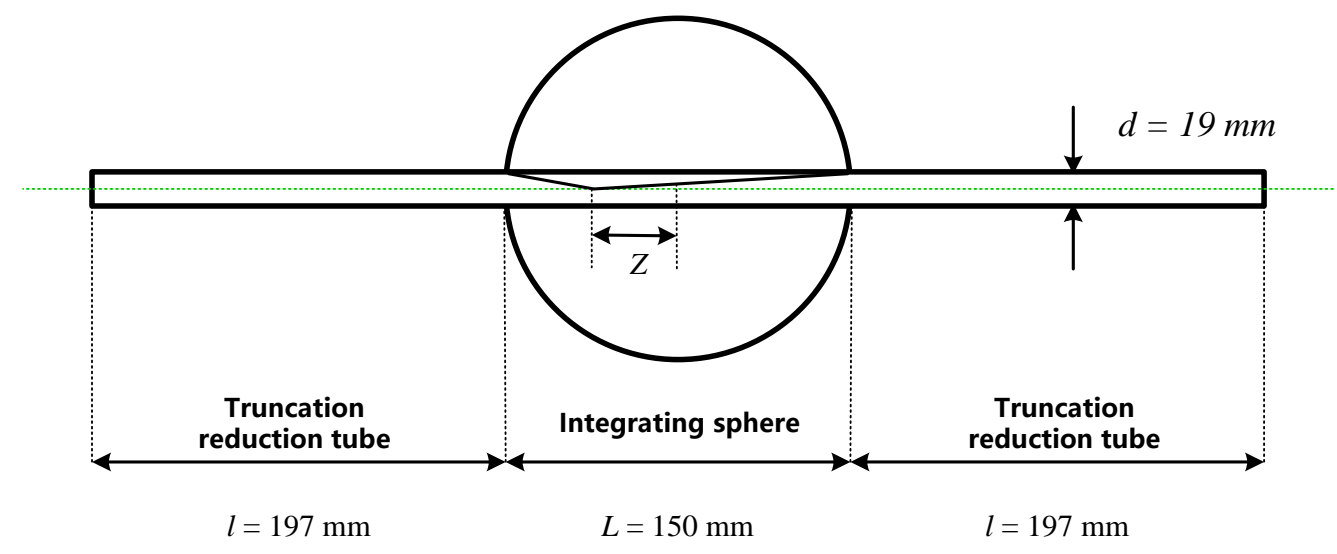

Figure S2 Sample cell geometry of the cavity-enhanced albedometer.

The albedometer truncation error was evaluated with Mie theory by considering the geometry of the cell and the scattering phase function of spherical particles (Moosmüller and Arnott, 2003; Zhao et al., 2014; Onasch et al., 2015). The scattering truncation of the particles with a certain diameter $(D)$ inside the cell $(T(D, \theta))$ is defined as the ratio of the integrated scattering efficiencies of the effective truncation angles to the total scattering efficiency, which can be expressed as following (Onasch et al., 2015):

$$
T(D, \theta)=\int_{\theta_{1}}^{\theta_{2}} \frac{2 I(D, \theta)}{\chi^{2} Q_{s c a}(m, x, \lambda)} \sin (\theta) d \theta
$$

where $\theta_{1}$ and $\theta_{2}$ are the effective truncation angles, $I(D, \theta)$ is the unpolarized scattering intensity, $m$ is the complex refractive index (CRI, $m=n+i k$ ), $\lambda$ is the wavelength of incident light, $x=\pi D / \lambda$ is the size parameter, and $Q_{s c a}(m, x, \lambda)$ is the scattering efficiency.

The effective truncation angle $(\theta)$ depends upon the position of particles within the cell, which can be expressed as (Varma et al., 2003; Zhao et al., 2014):

$$
\theta_{1}(Z)=\tan ^{-1}\left(\frac{d / 2}{L / 2+Z}\right), \theta_{2}(Z)=\tan ^{-1}\left(\frac{d / 2}{-L / 2-Z}\right)
$$


The total scattering truncation can be written as follows (Onasch et al., 2015):

$$
T(D)=\int_{Z_{1}}^{Z_{2}} \theta_{\theta_{1}(Z)}^{\theta_{2}(Z)} \frac{2 I(D, \theta)}{\chi^{2} Q_{s c a}(m, x, \lambda)} \sin (\theta) d \theta d Z
$$

where the end points of $Z$ integration are defined as:

$$
Z_{1}=-\frac{1}{2} L-l, Z_{2}=\frac{1}{2} L+l
$$

A plot of the total scattering truncation of PSL particles with different diameters of our cavity-enhanced albedometer and that of $\mathrm{PM}_{\text {ssa }}$ reported by Onasch et al. (2015) is shown in Fig S3. By using longer truncation reduction tubes and larger inner diameter integrating sphere, the truncation losses of our albedometer are smaller than that of CAPS PMSSA monitors.

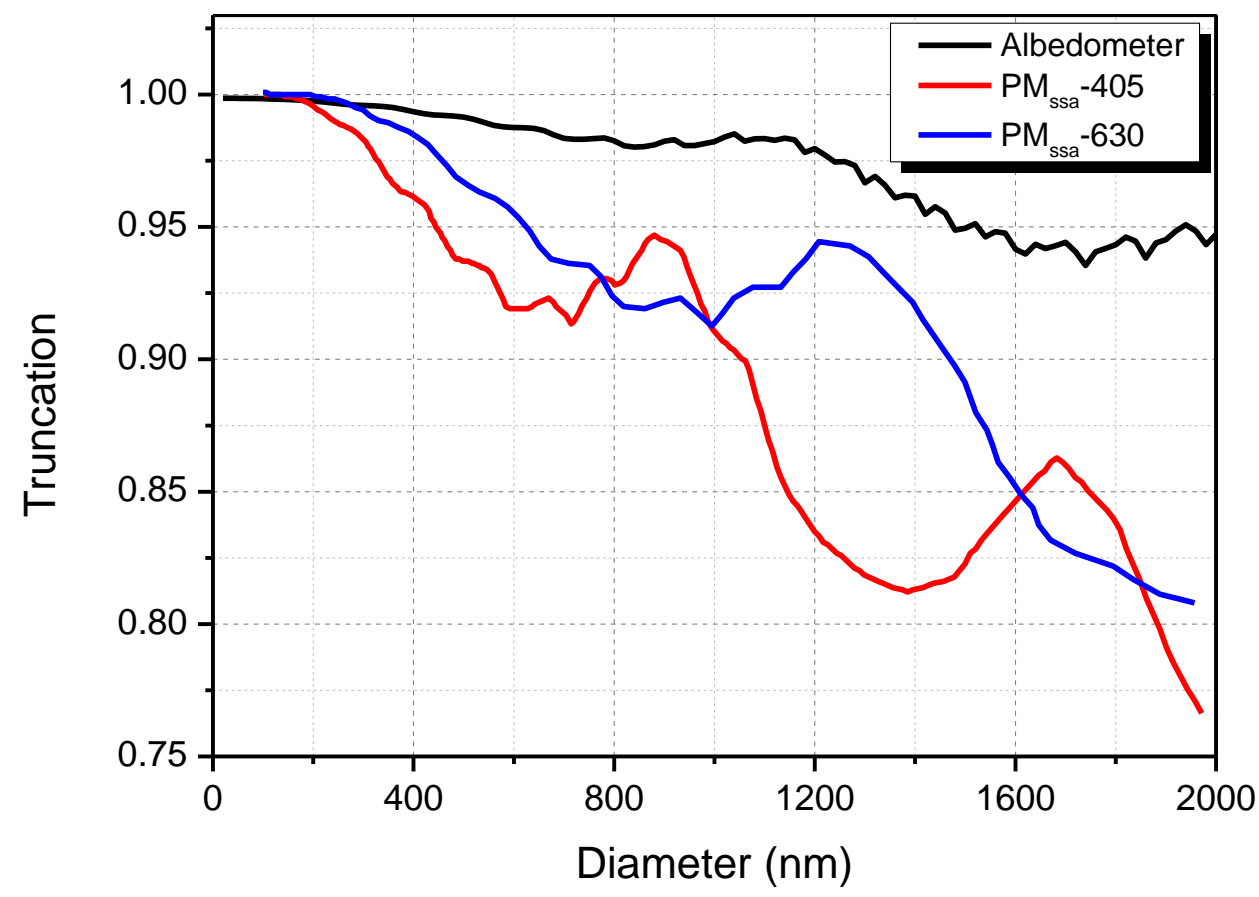

Figure S3 Comparison of the scattering truncations for PSL particles of our albedometer (at $\lambda=532 \mathrm{~nm}$ ) and that for CAPS PM ssa $_{\text {(at }} \lambda=405,630 \mathrm{~nm}$ ). The complex refractive index of PSL was set to be 1.59 $+i 0.0$.

Three different CRI values were used to represent the scattering truncation of different-type particles: the non-absorbing $(1.55+i 0)$; absorbing $(1.55+i 0.01)$; and strongly absorbing $(1.85+i 0.71)$ particles (treated as black carbon). As shown in Fig. S4, the calculated truncations decreased with increasing of particle size and imaginary part of CRI. 


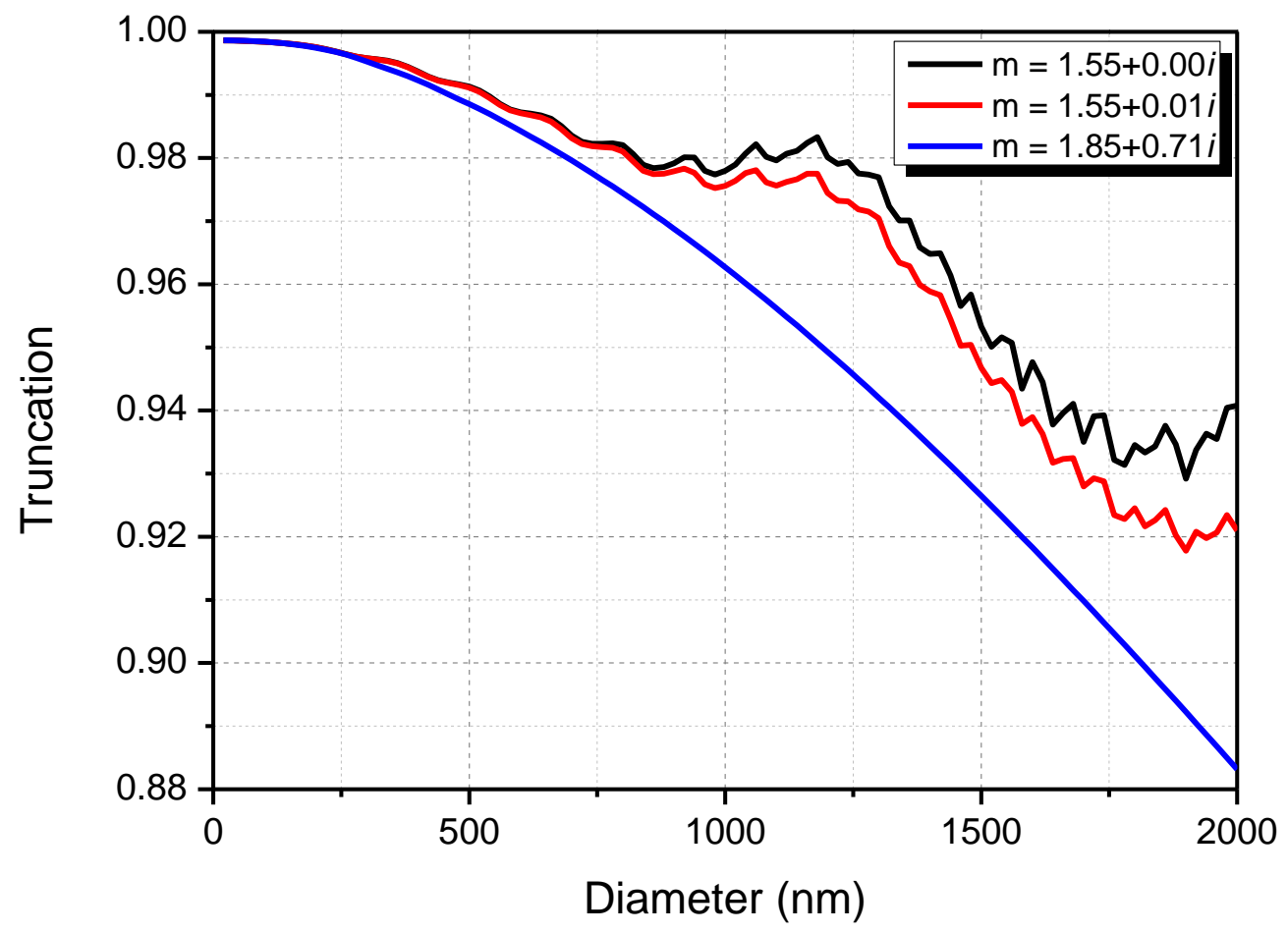

Figure S4 Scattering truncation calculated by the Mie model for three different type particles at $\lambda=532$ nm.

The accumulative truncation errors (ATE) based on the SMPS data (integrated with the normalized number size distribution of ambient aerosol) can be expressed as follows:

$$
A T E=\int f\left(D_{i}\right)\left(1-T\left(D_{i}\right)\right) d D_{i}
$$

where $D_{i}$ is the particle diameter, $f\left(D_{i}\right)$ is the normalized particle number distribution, $T\left(D_{i}\right)$ is the scattering truncation of the corresponding diameter. As shown in Fig. S5, the accumulative truncation errors for three different type particles are all smaller than $0.2 \%$. Thus, the truncation errors of the measured scattering coefficients were negligible for fine particles in this work. 


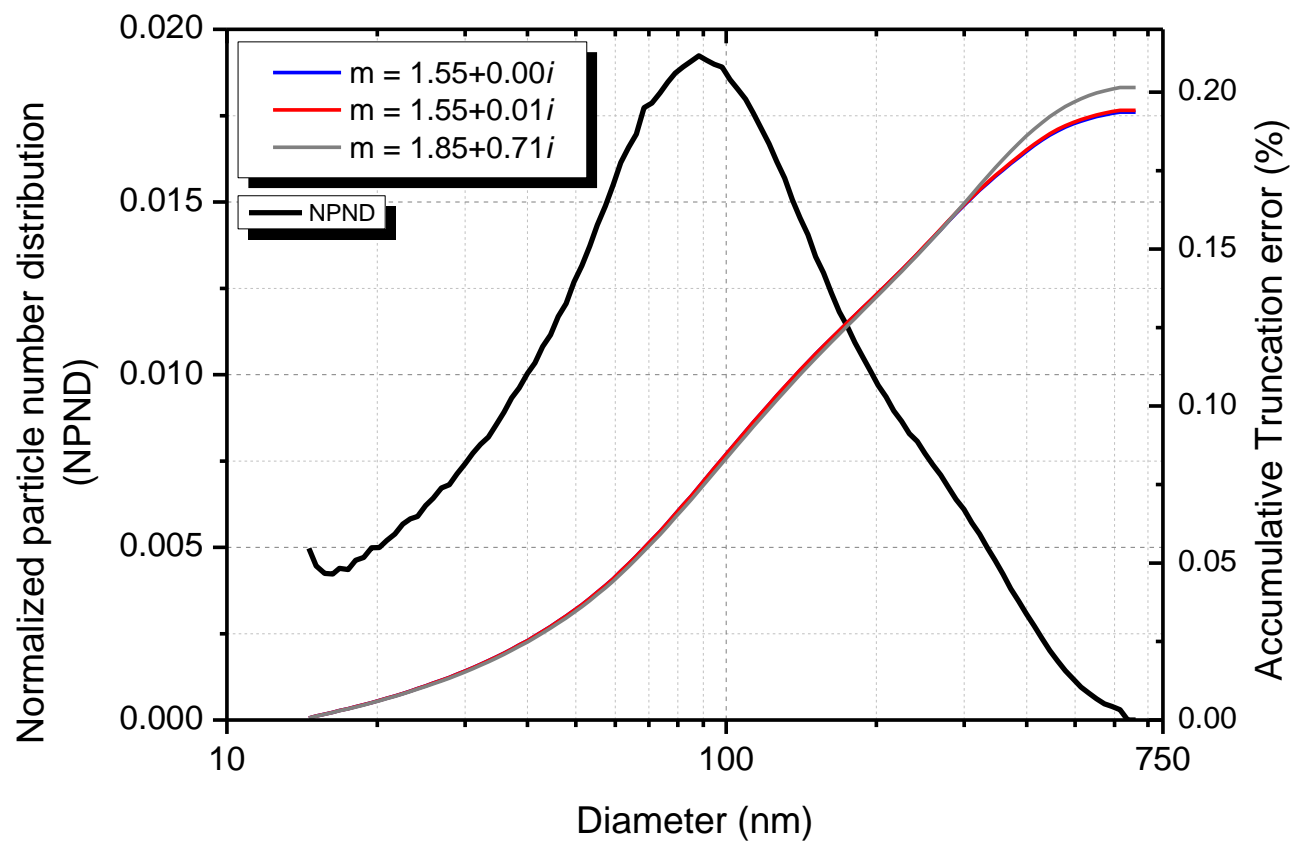

Figure S5 Averaged normalized particle number distribution during the observation period and the corresponding accumulative truncation errors at each size. 


\section{S3 Particle losses inside the thermodenuder}

Laboratory-generated polydisperse $\mathrm{NaCl}$ particles (with TSI 3076 constant output atomizer) were used to estimate the particle losses inside the thermodenuder (TD). Particles were dried to RH < 5\% with a silica gel diffusion dryer (TSI 3062), neutralized with an aerosol neutralizer (TSI 3077), and then diluted with a buffer to obtain a stable aerosol concentration. The size resolved TD losses are shown in Fig. S6. The measured particle losses agreed with manufactory given data (Dekati Ltd., Technical Note, 2001).
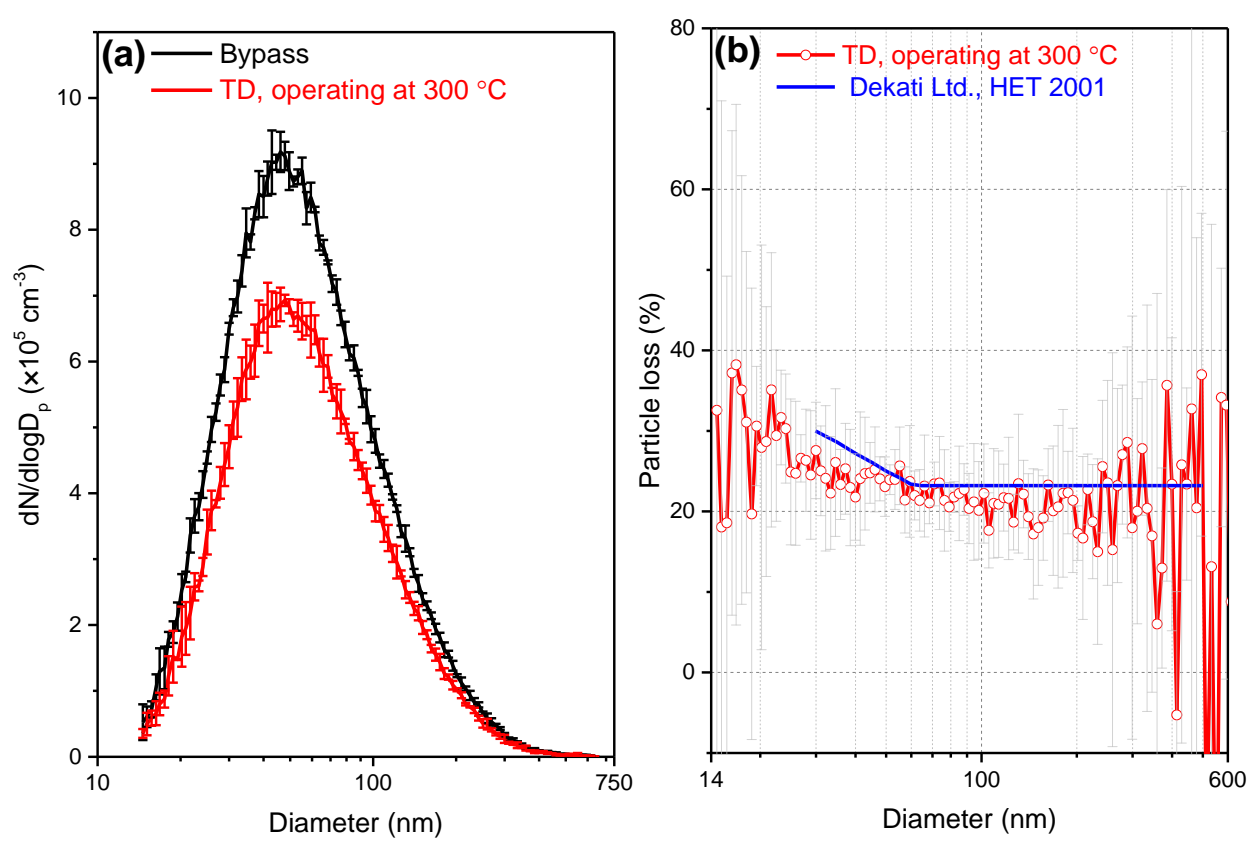

Fig. S6: (a) The changes of particle number distribution of $\mathrm{NaCl}$ particles passed through the bypass and the TD operating at $300{ }^{\circ} \mathrm{C}$. (b) Size resolved particle losses of the TD. Manufactory given losses (blue line, Dekati Ltd., HET. 2001) are also shown in the figure.

Due to the small absorption cross section, the contribution of small particle to aerosol absorption is negligible. Particle number losses may not exactly the same as the optical losses. In this work, laboratory-generated polydisperse $\mathrm{NaCl}$ particles and ambient sample before and after passing through of the TD were used to estimate the actual optical losses inside the TD. The corresponding measured extinction and scattering coefficients for $\mathrm{NaCl}$ are shown in the upper panel of Fig. S7. The TD loss was estimated to be $\sim 26 \%$ for both scattering and extinction. The results for ambient sample were shown in 
the lower panel of Fig. S7. The TD losses for both channels were estimated to be $\sim 32 \%$, which are comparable to the estimated losses of absorption of black carbon ( $32 \pm 3 \%$ at $\lambda=370 \mathrm{~nm}$, and $24 \pm 6 \%$ at $\lambda=880 \mathrm{~nm}$ ) (Devi et al., 2016). In this work, we use actual TD loss of ambient aerosol $32 \%$ for further data analysis.
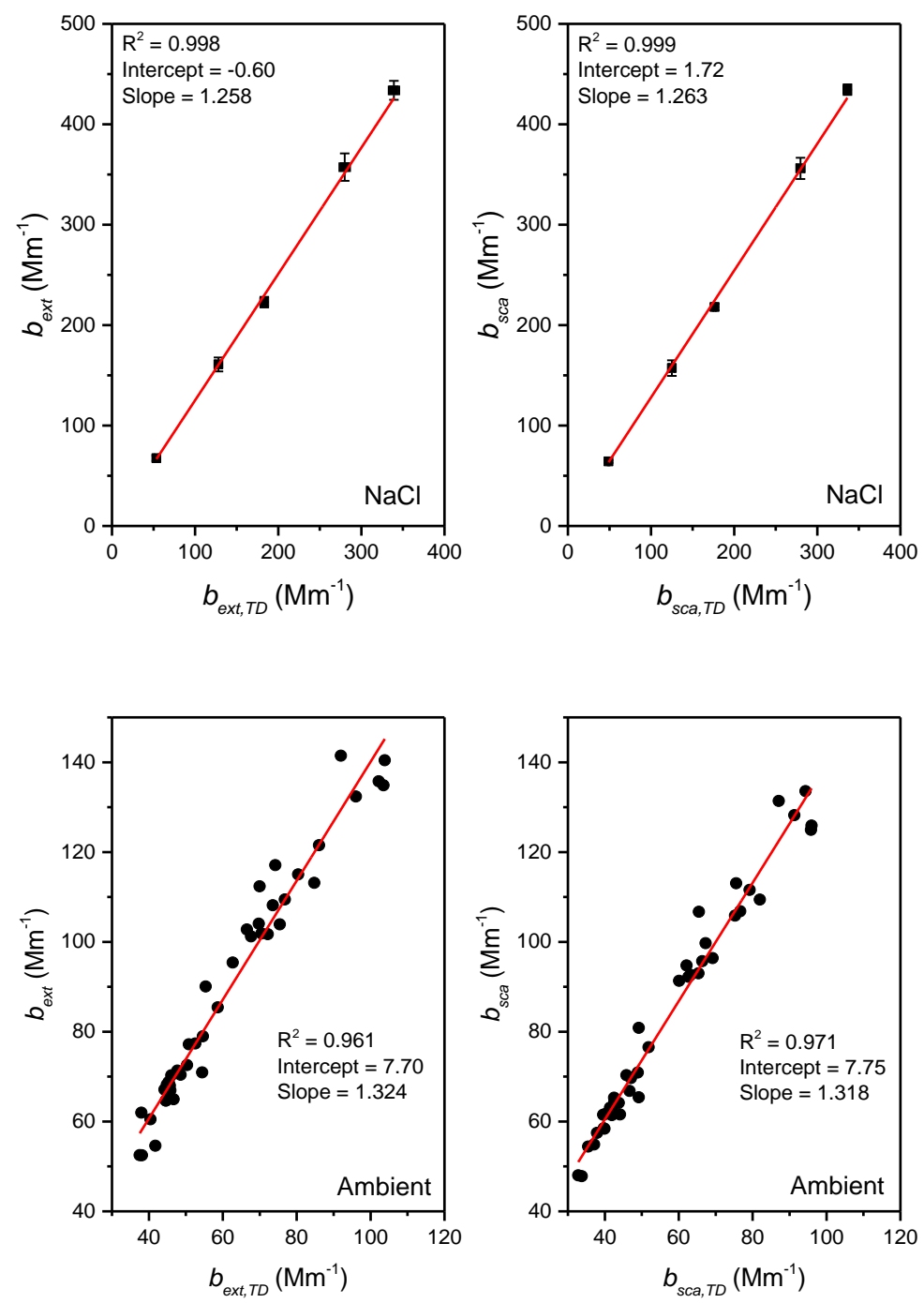

Figure S7: Scatter plot of the measured extinction and scattering coefficients of $\mathrm{NaCl}$ (upper panel, operating at $300{ }^{\circ} \mathrm{C}$ ) and ambient particles (lower panel, operating at room temperature) before ( $b_{\text {ext } t \text { scat }}$ ) and after $\left(b_{\text {ext,scat }}, T D\right)$ passing through the TD. 


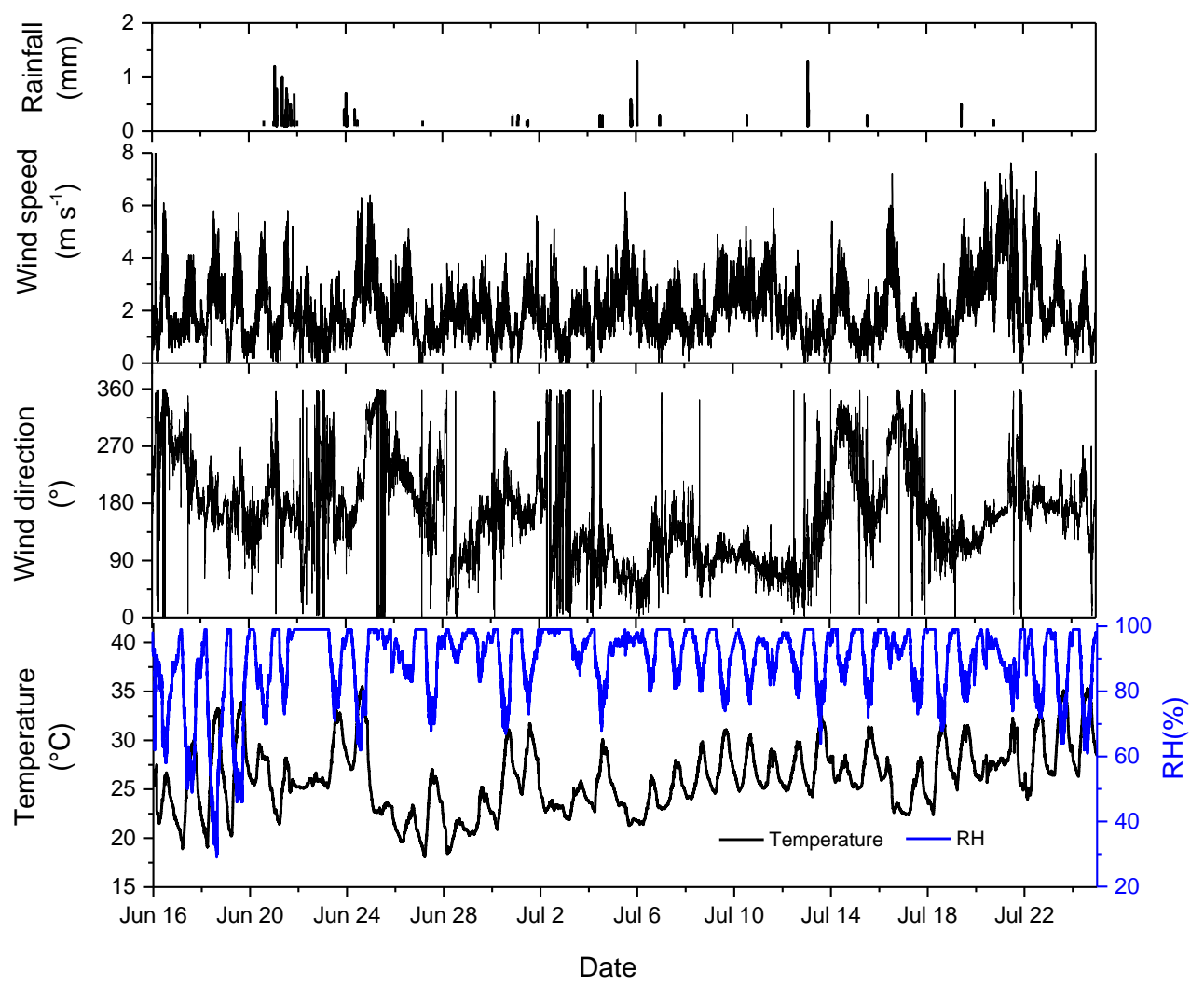

Figure S8: Time profiles of rainfall, wind speed, wind direction, temperature, and relative humidity (RH) during the measurement period. 

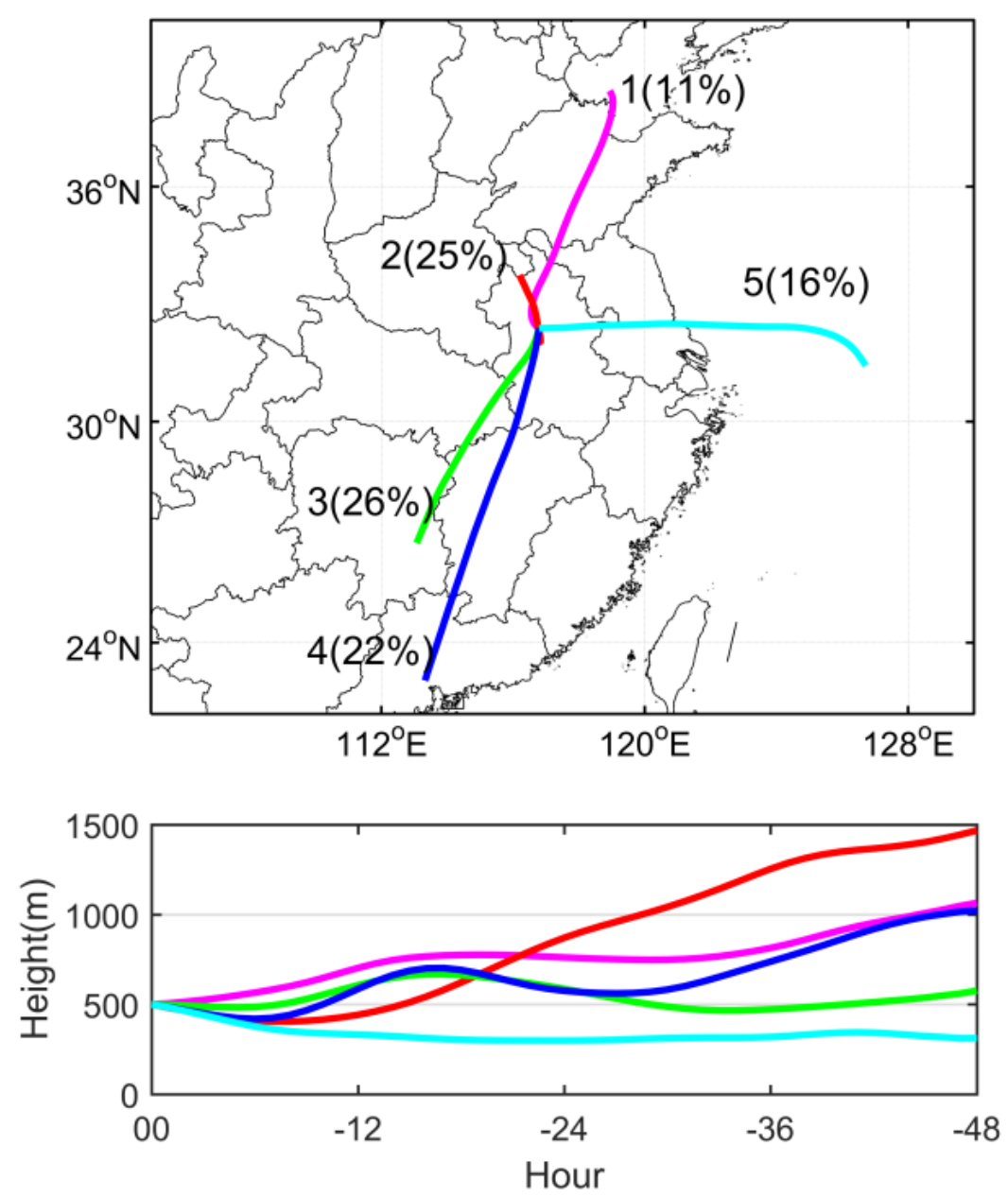

Figure S9: The $48 \mathrm{~h}$ back trajectories ending at $500 \mathrm{~m}$ above ground level at the Shouxian site (calculated every $1 \mathrm{~h}$ ) were classified into five groups using the clustering method given by HYSPLIT model. 
S6 Case study of the correlation between $\omega, \omega \mathrm{TD}$, Eabs and $O_{x}$

Case 1:

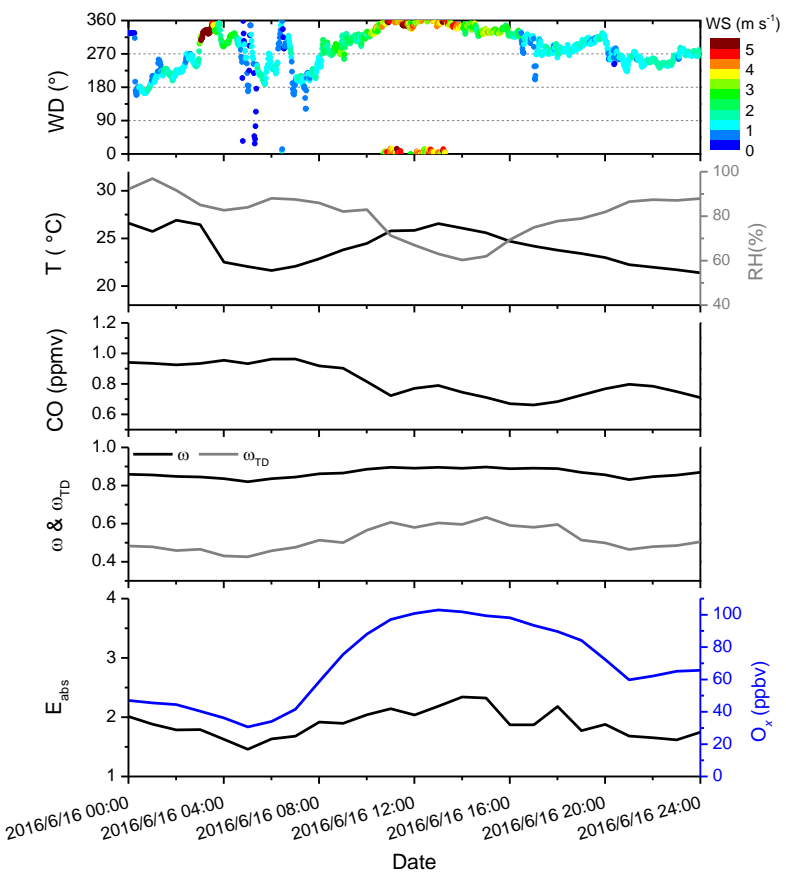

Case 2:

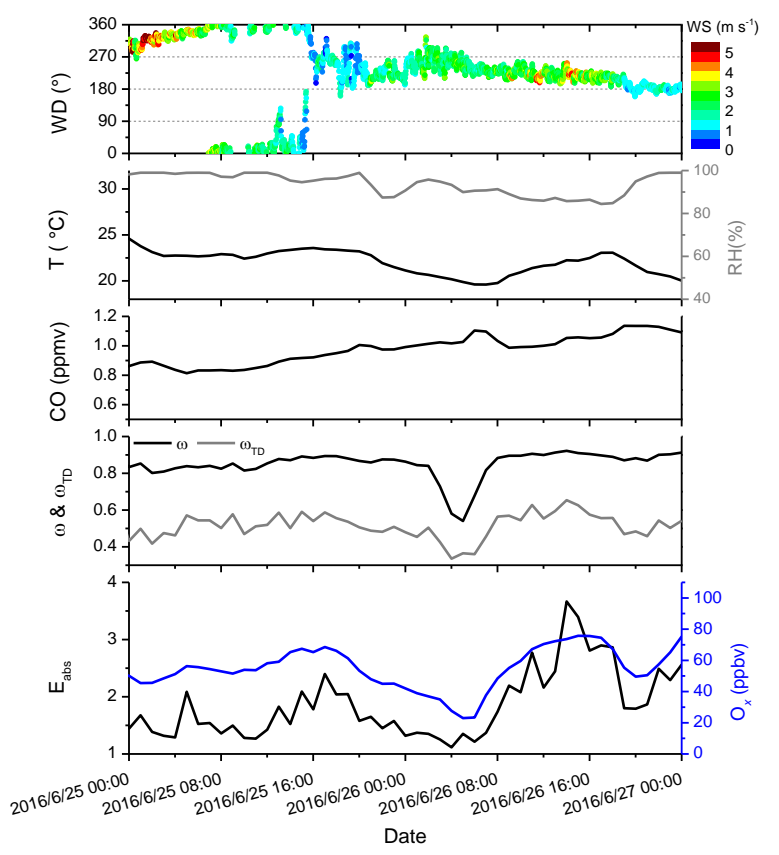




\section{Case 3:}

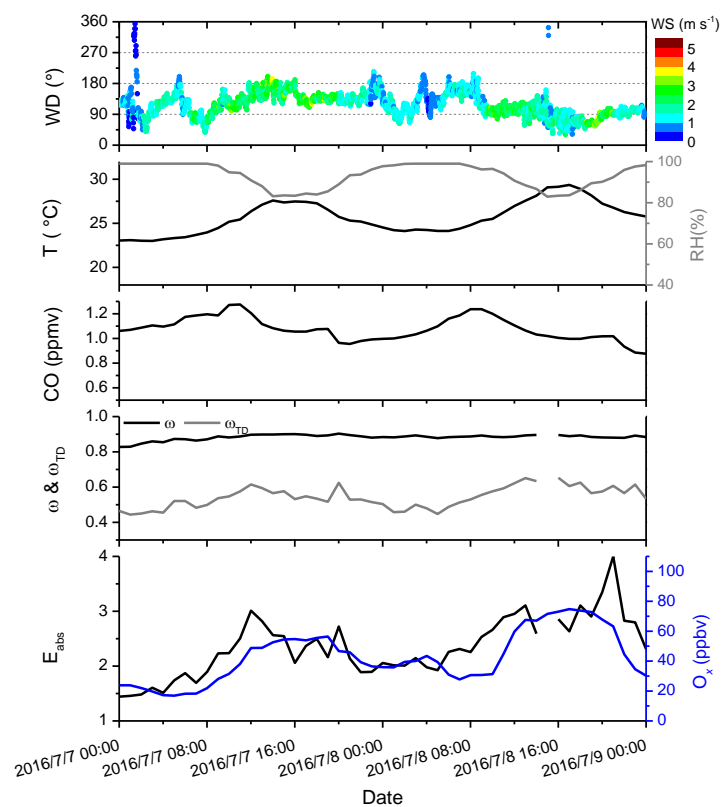

Case 4:
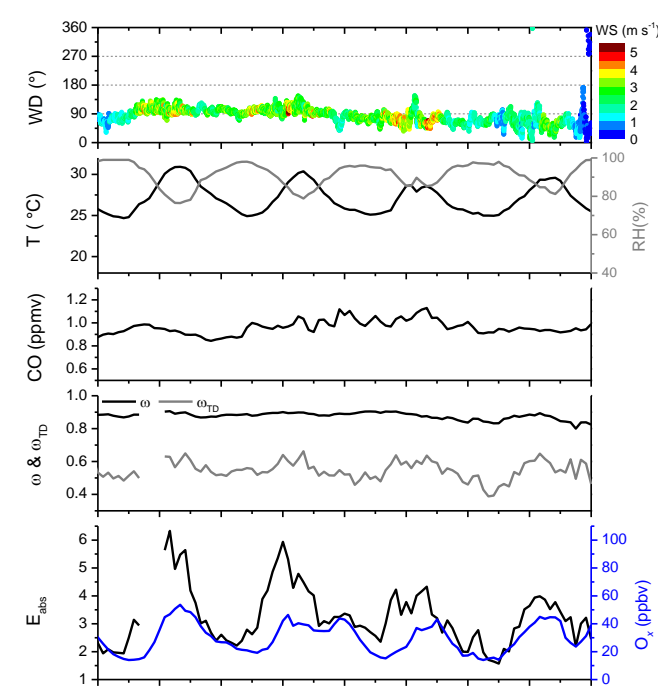

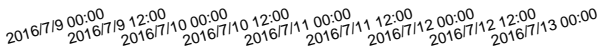

Figure S10: Time series of wind direction (WD, colored by wind speed (WS)), air temperature (T) and relative humidity $(\mathrm{RH}), \mathrm{CO}$ concentrations, $\omega, \omega_{\mathrm{TD}}, \mathrm{E}_{\mathrm{abs}}$ and $\mathrm{O}_{\mathrm{x}}$ concentrations for the four selected cases. 


\section{S7 Mie theory modelling and attribution of light absorption}

A graphical representation of the calculation procedure is shown in Fig. S11. Comparisons of modeling and observation $\mathrm{E}_{\mathrm{abs}}$ and SSA are shown as a scatter plot in Fig. S12.

The calculation of the model is as follows:

(a) Initial inputs parameters are the diameter of $\mathrm{BC}$ core $\left(\mathrm{D}_{\text {core }}\right), \mathrm{CRI}$ of core $\left(m_{\mathrm{BC}}\right)$ and real part of the CRI of shell ( $\left.n_{\text {shell }}\right)$;

In this work, $m_{\mathrm{BC}}$ at $\lambda=532 \mathrm{~nm}$ was fixed at $1.85+i 0.71$, and $n_{\text {shell }}$ was fixed at 1.55 (Bond and

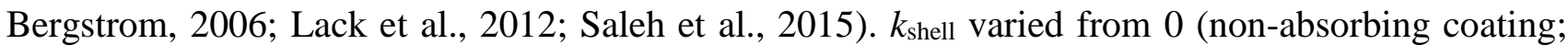
clear shell) to 0.1 (strongly absorbing coating) (Lack and Cappa., 2010). $\mathrm{D}_{\text {core }}$ was constrained between 50 and $400 \mathrm{~nm}$, while $\mathrm{D}_{\text {shell }}$ ranged from 50 (for thinly coated $\mathrm{BC}$ ) to $800 \mathrm{~nm}$ (for thickly coated BC).

(b) Calculate the extinction, scattering and absorption coefficients ( $b_{\text {ext }}, b_{\text {sca, }}$, and $\left.b_{\text {abs }}\right)$ of the $\mathrm{BC}$ core and coated particles with different $k_{\text {shell }}$ and $\mathrm{D}_{\text {shell }}$ using the core-shell model;

(c) Calculate $\mathrm{E}_{\mathrm{abs}}$ and $\omega$ from the calculated $b_{\text {ext }}, b_{\text {sca }}$, and $b_{\text {abs }}$ of bare $\mathrm{BC}$ and coated particles;

(d) Determine a set of optimized $\mathrm{D}_{\text {shell }}$ and $k_{\text {shell }}$ values by minimizing the "merit function", $\chi^{2}$ :

$$
\chi^{2}=\frac{\left(\omega-\omega_{c a l c}\right)^{2}}{\varepsilon_{\omega}^{2}}+\frac{\left(E_{a b s}-E_{a b s, c a l c}\right)^{2}}{\varepsilon_{E_{a b s}}^{2}}
$$

Here, $\omega$ and $\mathrm{E}_{\mathrm{abs}}$ are the observed values, $\omega_{\text {calc }}$ and $\mathrm{E}_{\mathrm{abs}, \mathrm{calc}}$ are the corresponding calculated values, and $\varepsilon_{\omega}$ and $\varepsilon_{\text {Eabs }}$ are the measurement uncertainties of $\omega$ and $\mathrm{E}_{\mathrm{abs}}$, respectively.

(e) The outputs of (d) are the optimized $\mathrm{D}_{\text {shell }}, k_{\text {shell }}, \mathrm{E}_{\mathrm{abs}, \text { calc }}$ and $\omega_{\text {calc }}$ for a given $\mathrm{D}_{\text {core }}$ in (a). A linear fit (as shown in Fig. S12) of the calculated and observed $\mathrm{E}_{\mathrm{abs}}$ and $\omega$ with different $\mathrm{D}_{\text {core }}$ was performed. A lookup table (in $10 \mathrm{~nm}$ step increments) was built to find the optimized $\mathrm{D}_{\text {core }}$ (bold text in the supplement Table S1). In this work, the optimized $\mathrm{D}_{\text {core }}$ was determined to be $160 \mathrm{~nm}$. This result falls within the diameter range of $120-165 \mathrm{~nm}$ reported by C. Wu et al. (2018), as well as the SP2 measurement results of $\mathrm{rBC}$, which ranged from $110-220 \mathrm{~nm}$ in different megacities in China (Huang et al., 2011; Wang et al., 2015; Gong et al, 2016; Y. Wu et al., 2018). 
Table S1: Lookup table of the linear fit (intercept, slope, and $\mathrm{R}^{2}$ ) of calculated and observed $\mathrm{E}_{\mathrm{abs}}$ and $\omega$ for different BC core diameters $\left(D_{\text {core }}\right)$.

\begin{tabular}{|c|c|c|c|c|c|c|}
\hline$D_{\text {core }}(\mathrm{nm})$ & $\begin{array}{l}\text { Intercept- } \\
\mathrm{E}_{\mathrm{abs}}\end{array}$ & Slope-Eabs & $\mathrm{R}^{2}-\mathrm{E}_{\mathrm{abs}}$ & Intercept- $\omega$ & Slope- $\omega$ & $\mathrm{R}^{2}-\omega$ \\
\hline 50 & 0.6936 & 0.7268 & 0.9283 & -0.076 & 1.0874 & 0.9681 \\
\hline 60 & 1.1900 & 0.5496 & 0.8872 & -0.0917 & 1.1044 & 0.9764 \\
\hline 70 & 1.3963 & 0.4697 & 0.8363 & -0.0865 & 1.0982 & 0.9746 \\
\hline 80 & 1.1822 & 0.5455 & 0.8273 & -0.0439 & 1.0498 & 0.9857 \\
\hline 90 & 0.7284 & 0.7126 & 0.9007 & -0.0022 & 1.0025 & 0.9899 \\
\hline 100 & 0.1847 & 0.9277 & 0.9716 & -0.0247 & 1.0284 & 0.9955 \\
\hline 110 & -0.0062 & 1.0051 & 0.9953 & 0.0055 & 0.9938 & 0.9974 \\
\hline 120 & 0.0221 & 0.9905 & 0.9975 & 0.0047 & 0.9946 & 0.9983 \\
\hline 130 & 0.0204 & 0.9913 & 0.9982 & -0.001 & 1.0012 & 0.9992 \\
\hline 140 & -0.0050 & 1.0013 & 0.9988 & -0.0052 & 1.0059 & 0.9990 \\
\hline 150 & 0.0050 & 0.9975 & 0.9981 & -0.0030 & 1.0035 & 0.9995 \\
\hline 160 & -0.0061 & 1.0027 & 0.9988 & -0.0000 & 1.0003 & 0.9995 \\
\hline 170 & -0.0125 & 1.0055 & 0.9986 & -0.0034 & 1.0039 & 0.9996 \\
\hline 180 & -0.0013 & 1.0060 & 0.9990 & 0.0088 & 0.9900 & 0.9995 \\
\hline 190 & 0.0042 & 0.9984 & 0.9990 & 0.00310 & 0.9965 & 0.9994 \\
\hline 200 & 0.0007 & 0.9998 & 0.9994 & -0.0022 & 1.0025 & 0.9994 \\
\hline 210 & 0.0081 & 0.9967 & 0.9992 & 0.0058 & 0.9933 & 0.9998 \\
\hline 220 & 0.0126 & 0.9950 & 0.9994 & 0.0033 & 0.9962 & 0.9997 \\
\hline 230 & -0.0194 & 1.0088 & 0.9992 & -0.0034 & 1.0039 & 0.9998 \\
\hline 240 & 0.0104 & 0.9947 & 0.9995 & 0.0015 & 0.9982 & 0.9998 \\
\hline 250 & -0.0001 & 0.9996 & 0.9994 & 0.0003 & 1.0004 & 0.9998 \\
\hline 260 & 0.0116 & 0.9951 & 0.9993 & 0.0020 & 0.9977 & 0.9998 \\
\hline 270 & 0.0108 & 0.9956 & 0.9988 & -0.0034 & 1.0040 & 0.9996 \\
\hline 280 & 0.1358 & 0.9383 & 0.9913 & 0.0063 & 0.9926 & 0.9994 \\
\hline 290 & 0.2722 & 0.8780 & 0.9741 & 0.0170 & 0.9803 & 0.9988 \\
\hline 300 & 0.4059 & 0.8171 & 0.9470 & 0.0181 & 0.9790 & 0.9986 \\
\hline 310 & 0.6670 & 0.6987 & 0.9182 & 0.0342 & 0.9602 & 0.9973 \\
\hline 320 & 0.9994 & 0.5477 & 0.8223 & 0.0528 & 0.9386 & 0.9946 \\
\hline 330 & 1.3743 & 0.3769 & 0.5716 & 0.0697 & 0.9188 & 0.9911 \\
\hline 340 & 1.7566 & 0.1994 & 0.2040 & 0.0876 & 0.8980 & 0.9863 \\
\hline 350 & 2.0968 & 0.0364 & -0.0366 & 0.1099 & 0.8717 & 0.9846 \\
\hline
\end{tabular}




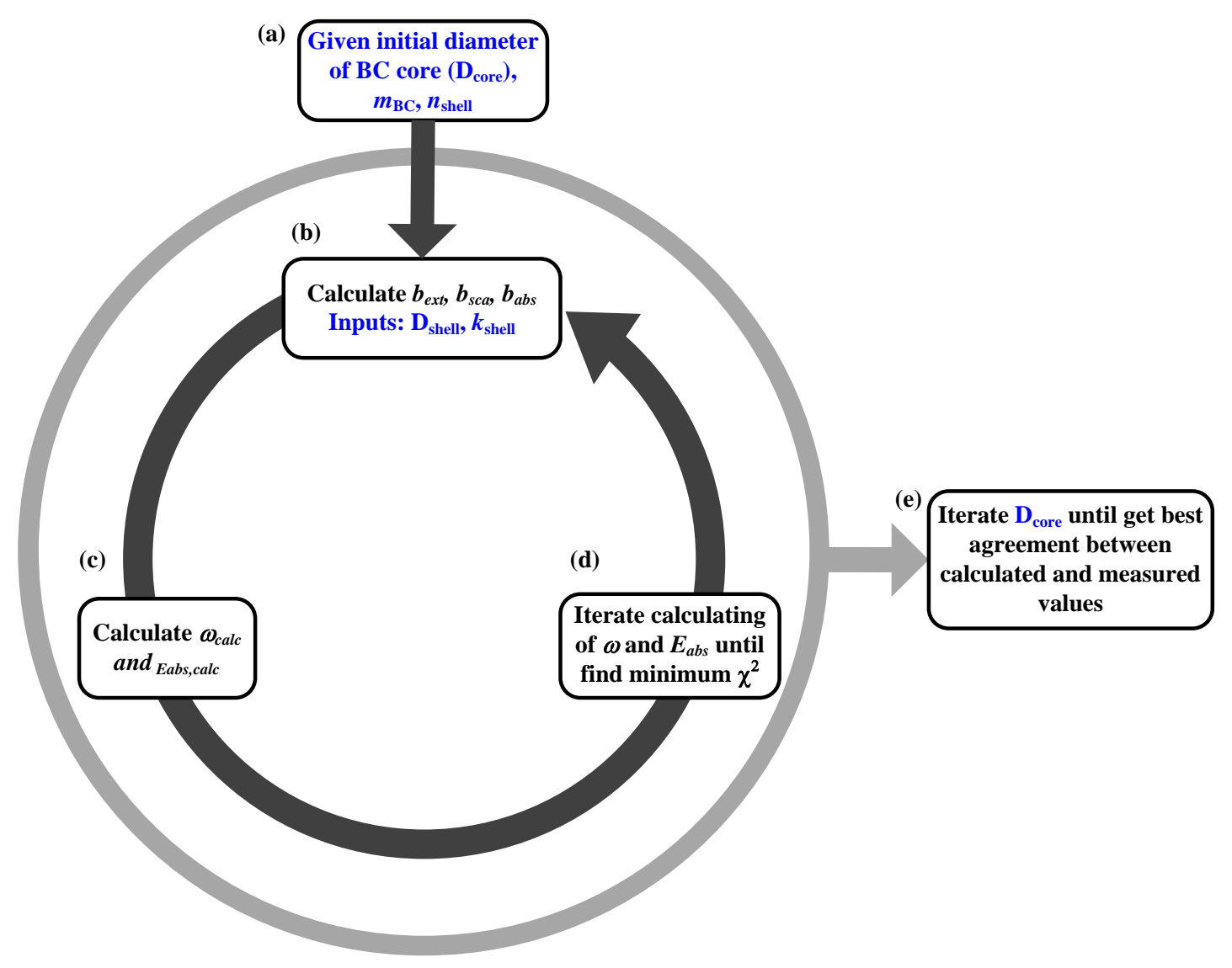

Figure S11 Optimization process for determining core $\left(D_{\text {core }}\right)$ and shell $\left(D_{\text {shell }}\right)$ diameters, and the imaginary part of CRI of the shell $\left(k_{\text {shell }}\right)$. 

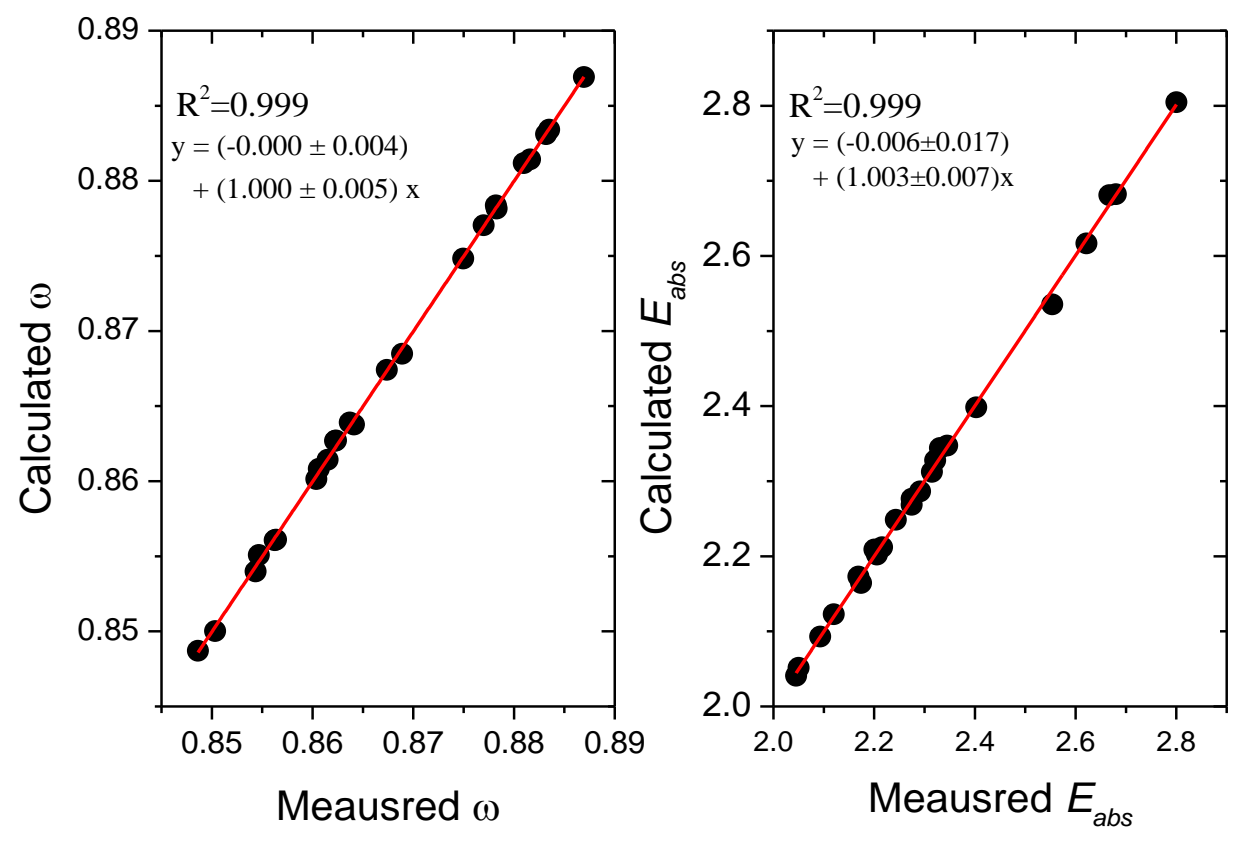

Figure S12 The comparisons of the measured and calculated $\mathrm{E}_{\mathrm{abs}}$ and $\omega$. 


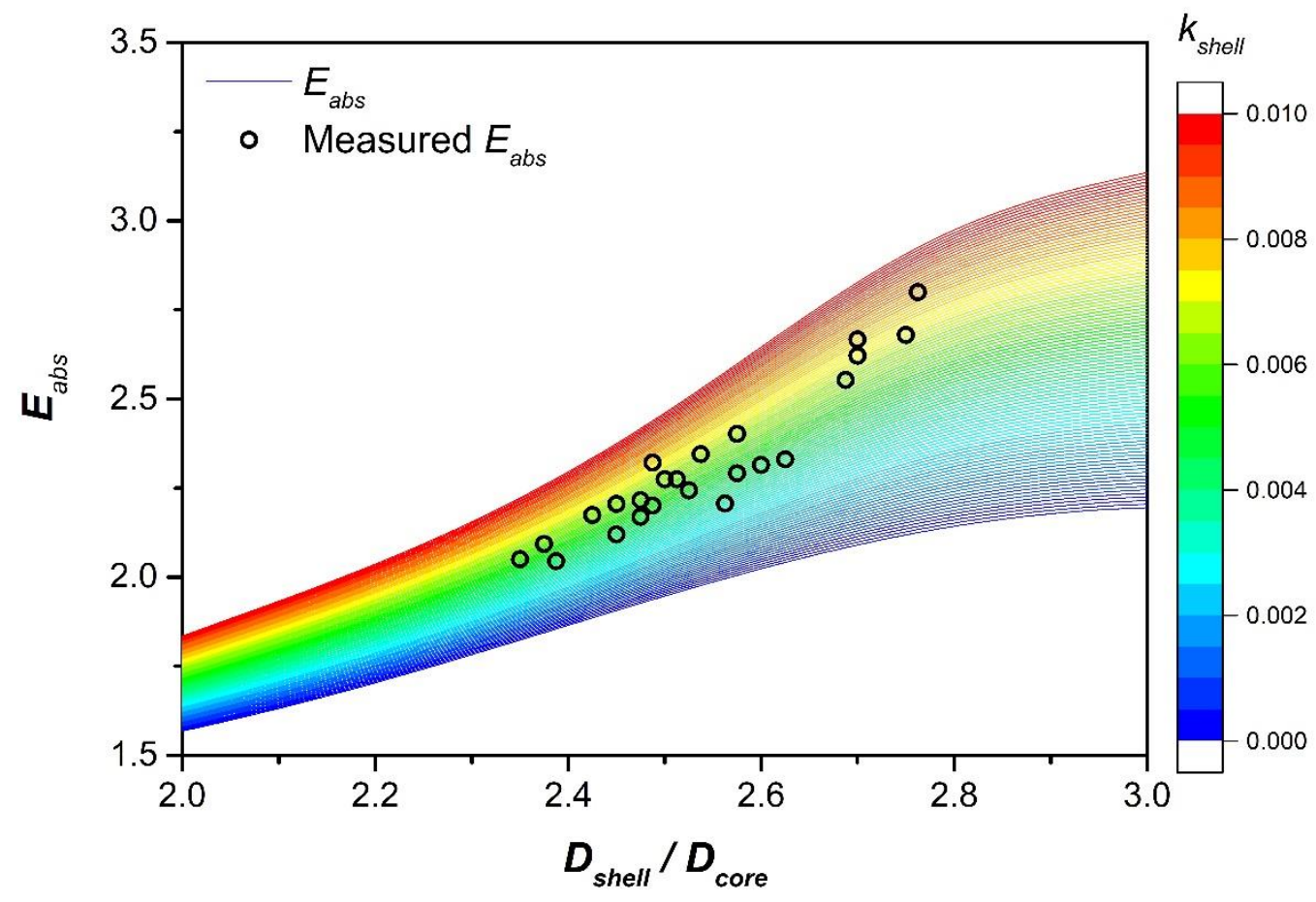

Figure S13 The plot of measured and modelled $E_{\text {abs }}$ values with different $D_{\text {shell }} / \mathrm{D}_{\text {core }}$. $\mathrm{D}_{\text {core }}$ is fixed at $160 \mathrm{~nm}$, and $\mathrm{D}_{\text {shell }}$ is ranged from 320 to $480 \mathrm{~nm}$. The imaginary parts $\left(k_{\text {shell }}\right)$ of complex refractive index ranged from 0 to 0.01 respectively present the clear and brown shell. 
Authropogenic SOM (Liu et al., 2015)

Toluene $+\mathrm{OH}$

- - - Toluene $+\mathrm{OH}+\mathrm{NO}_{x}$

$m$-Xylene $+\mathrm{OH}$

- - m-Xylene $+\mathrm{OH}+\mathrm{NO}_{x}$

Biogenic SOM (Liu et al., 2013)

a-pinene $+\mathrm{O}_{3}$

Limonene $+\mathrm{O}_{3}$

BrC spheres (Allexander et al., 2008)

Fulvic acid (Liu et al., 2015)

- = - SRFA (Bluvshtein et al., 2016)

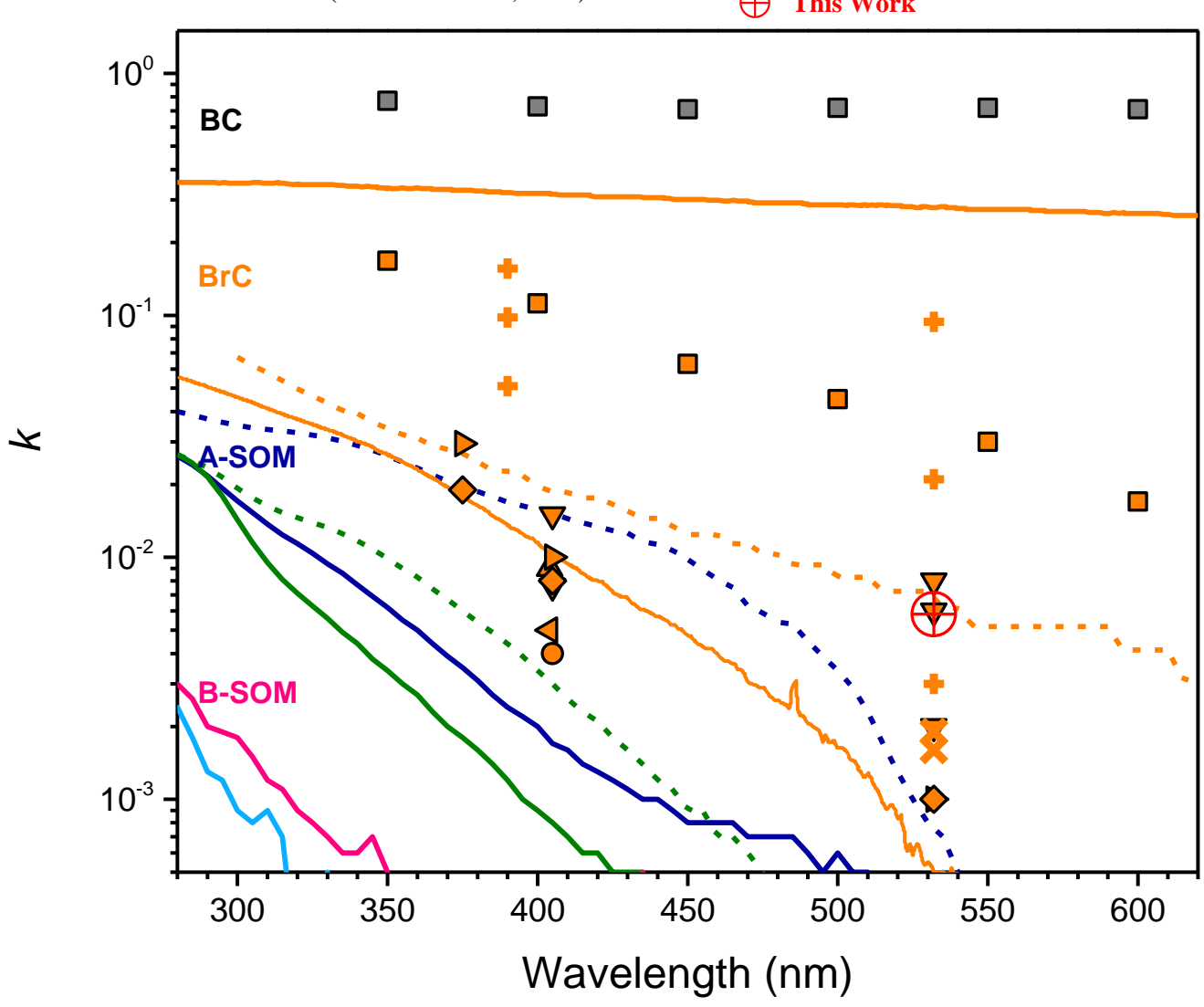

Black carbon (Kirchstetter et al., 2004)

$\square$ BB (Kirchstetter et al., 2004)

$\nabla$ BB (Chakrabarty et al., 2010)

HULIS (Hoffer et al., 2006)

$\triangleleft$ BB + Authrogenic (Lack et al., 2012)

$\triangle$ BB (Lack et al., 2012)

HULIS (Dinar et al., 2008)

O Urban BrC (Cappa et al., 2012)

$\triangleright$ Fresh BB (Sumlin et al., 2017)

$\checkmark$ Aged BB (Sumlin et al., 2017)

$\oplus$ This Work 


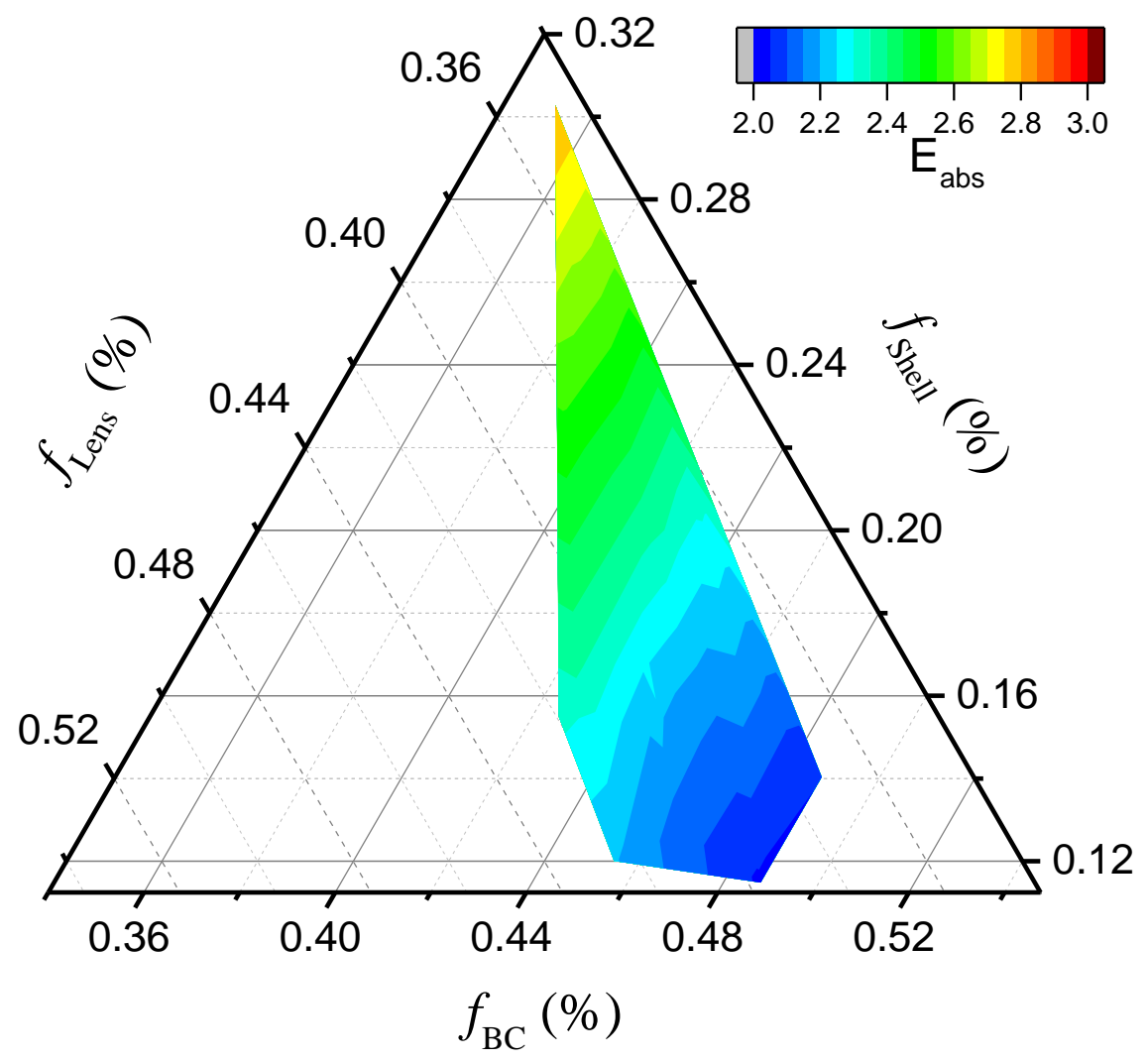

Figure S15: Ternary plot of the fractional contribution of lensing effect $\left(f_{\text {Lens }}\right)$, the absorption of BC $\left(f_{\mathrm{BC}}\right)$ and the shell $\left(f_{\text {Shell }}\right)$ to absorption enhancement (the values of $\mathrm{E}_{\mathrm{abs}}$ were colour-coded). 
Observed $E_{a b s}$

- Mie theory calculation (monodisperse BC core, $\mathrm{D}=160 \mathrm{~nm}$ )

- - Mie theory calculation (polydisperse BC core, GMD=160 nm, $\sigma=1.6$ )

- . Mie theory calculation (polydisperse BC core, GMD=120 nm, $\sigma=1.6$ )

- . - Mie theory calculation (polydisperse BC core, GMD=100 nm, $\sigma=1.6$ )

Mie theory calculation (polydisperse $\mathrm{BC}$ core, $\mathrm{GMD}=80 \mathrm{~nm}, \sigma=1.6$ )
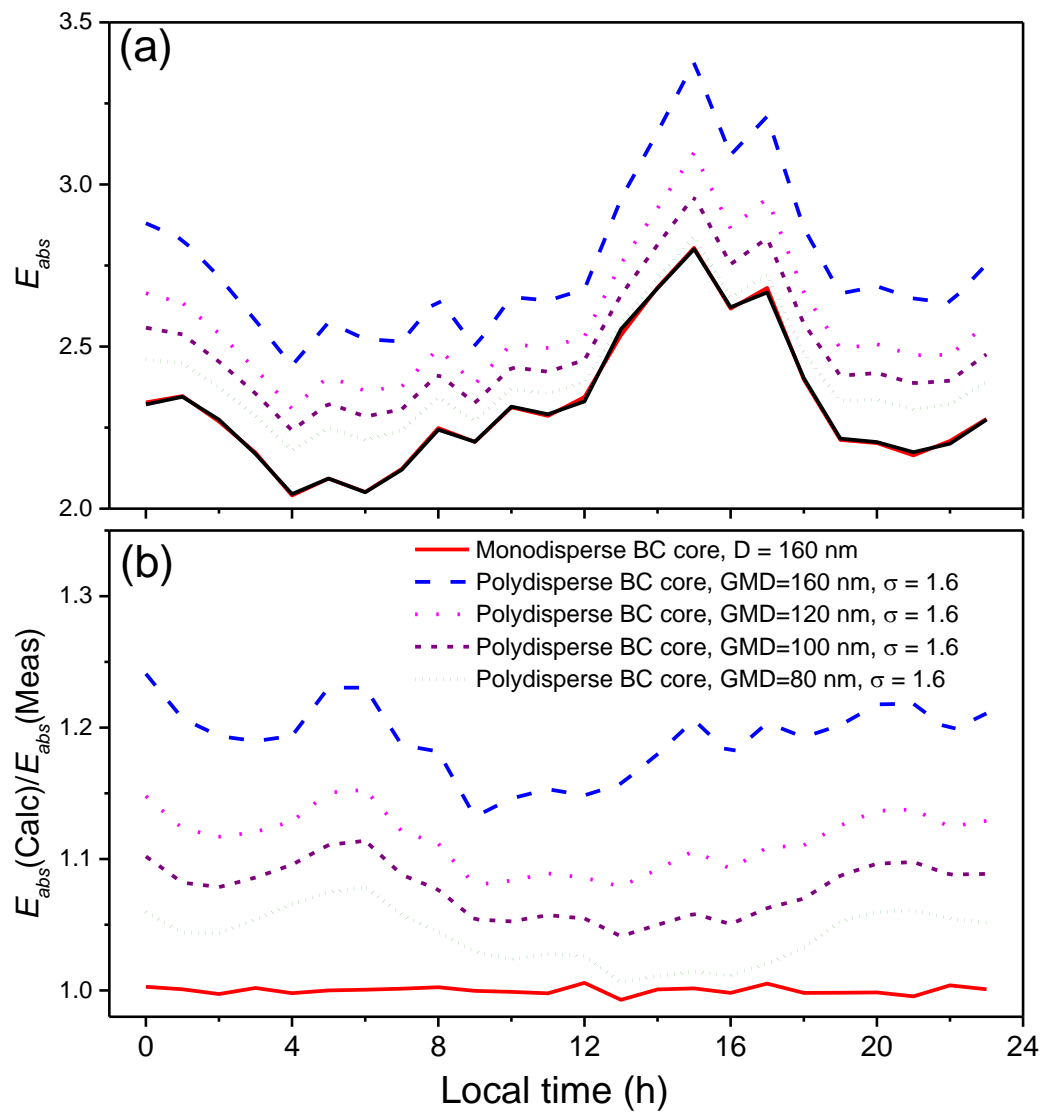

Figure S16: Comparison of the Mie theory results of $E_{a b s}$ with monodisperse BC core with $160 \mathrm{~nm}$ diameter and polydisperse size distributions with a geometric standard deviation of 1.6 and mode diameters of 160,120,100, and $80 \mathrm{~nm}$, respectively. The parameters used for the calculation are the same as in Fig. 8. Polydisperse BC core sizes have larger $\mathrm{E}_{\mathrm{abs}}$ values than monodisperse $\mathrm{BC}$ core; however, the trends of $E_{\text {abs }}$ values are same. We use an optimization process for determining $D_{\text {core }}, D_{\text {shell }}$, and $k_{\text {shell }}$; similar trends show that monodisperse $\mathrm{BC}$ core can be used for the interpretation of the measurement data. 


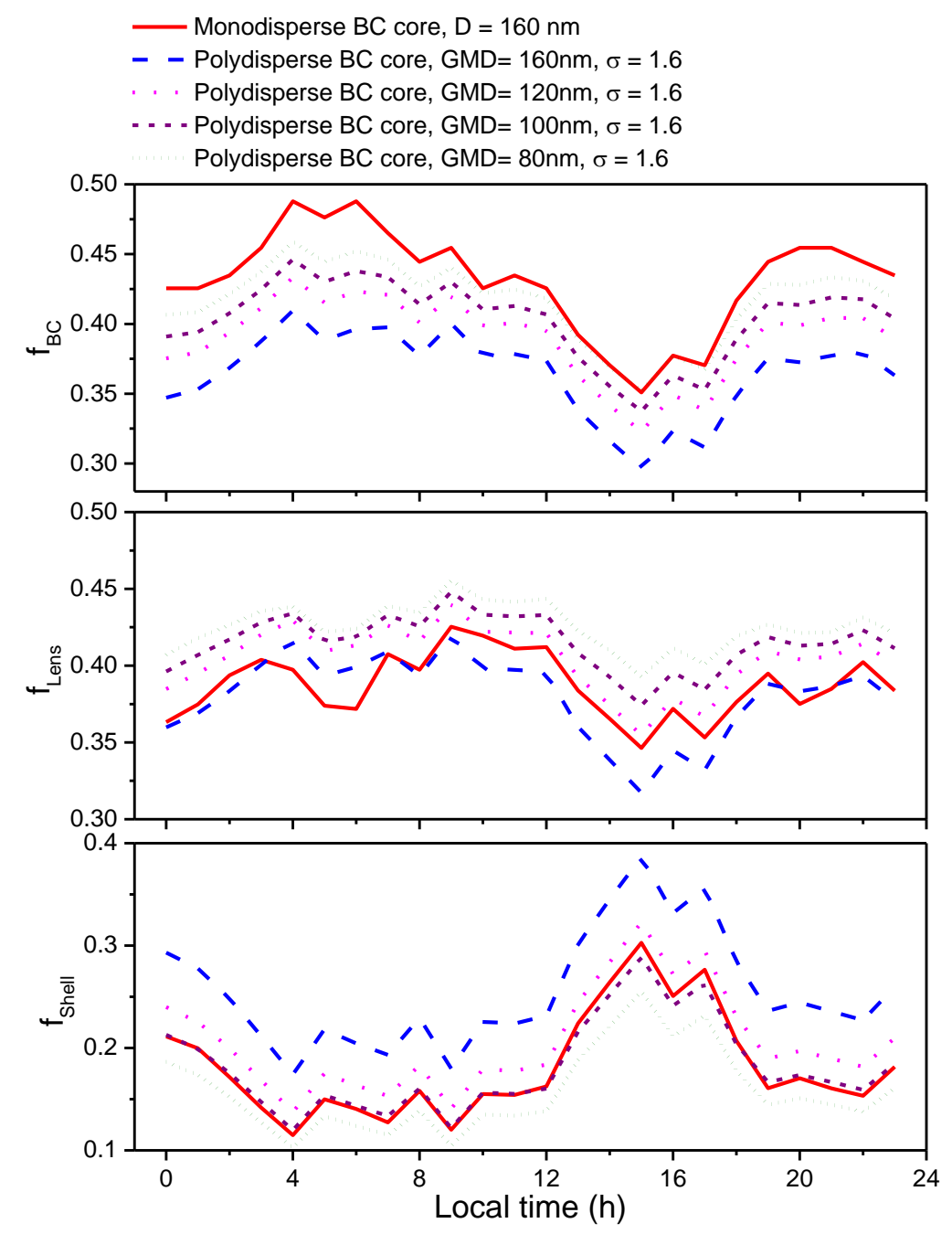

Figure S17: Fractional contribution of the lensing effect ( $\left.f_{\text {Lens }}\right)$, the absorption of BC $\left(f_{\mathrm{BC}}\right)$ and the shell $\left(f_{\text {Shell }}\right)$ to absorption enhancement with different BC core sizes as Fig. S16. The trends of the diurnal pattern are similar. The differences between these calculations are less than $10 \%$. 


\section{References:}

Alexander, D. T. L., Crozier, P. A., and Anderson, J. R.: Brown carbon spheres in East Asian outflow and their optical properties, Science, 321, 833-836, https://doi.org/10.1126/science.1155296, 2008.

Bluvshtein, N., Flores, J. M., Segev, L., and Rudich, Y.: A new approach for retrieving the UV-vis optical properties of ambient aerosols, Atmos. Meas. Tech., 9, 3477-3490, https://doi.org/10.5194/amt-9-3477-2016, 2016.

Bond, T. C., and Bergstrom, R. W.: Light Absorption by Carbonaceous Particles: An Investigative Review, Aerosol Sci. Technol., 40, 27-67, https://doi.org/10.1080/02786820500421521, 2006.

Cappa, C.D., Onasch, T.B., Massoli, P., Worsnop, D.R., Bates, T.S., Cross, E.S., Davidovits, P., Hakala, J., Hayden, K.L., Jobson, B.T., Kolesar, K.R., Lack, D.A., Lerner, B.M., Li, S.M., Mellon, D., Nuaaman, I., Olfert, J.S., Petäjä, T., Quinn, P.K., Song, C., Subramanian, R., Williams, E.J., Zaveri, R.A.: Radiative absorption enhancements due to the mixing state of atmospheric black carbon, Science, 337, 1078-1081, https://doi.org/10.1126/science.1223447, 2012.

Chakrabarty, R. K., Moosmüller, H., Chen, L.-W. A., Lewis, K., Arnott, W. P., Mazzoleni, C., Dubey, M. K., Wold, C. E., Hao, W. M., and Kreidenweis, S. M.: Brown carbon in tar balls from smoldering biomass combustion, Atmos. Chem. Phys., 10, 6363-6370, https://doi.org/10.5194/acp-10-6363-2010, 2010.

Dekati Ltd., HET. (2001). Sampling automotive exhaust with a thermodenuder. Dekati Ltd., Technical Note.

Devi, J. J., Bergin, M. H., Mckenzie, M., Schauer, J. J. and Weber, R. J.: Contribution of particulate brown carbon to light absorption in the rural and urban Southeast US, Atmos. Environ., 136, 95104, https://doi.org/10.1016/j.atmosenv.2016.04.011, 2016.

Dinar, E., Abo Riziq, A., Spindler, C., Erlick, C., Kiss, G., and Rudich, Y.: The complex refractive index of atmospheric and model humic-like substances (HULIS) retrieved by a cavity ring down aerosol spectrometer (CRD-AS), Faraday Discuss., 137, 279-295, https://doi.org/10.1039/b703111d, 2008.

Gong, X., Zhang, C., Chen, H., Nizkorodov, S. A., Chen, J., and Yang, X.: Size distribution and mixing state of black carbon particles during a heavy air pollution episode in Shanghai, Atmos. Chem. Phys., 16, 5399-5411, https://doi.org/10.5194/acp-16-5399-2016, 2016.

Hoffer, A., Gelencsér, A., Guyon, P., Kiss, G., Schmid, O., Frank, G. P., Artaxo, P., and Andreae, M. O.: Optical properties of humiclike substances (HULIS) in biomass-burning aerosols, Atmos. Chem. Phys., 6, 3563-3570, https://doi.org/10.5194/acp-6-3563-2006, 2006.

Huang, X. F., He, L. Y., Hu, M., Canagaratna, M. R., Kroll, J. H., Ng, N. L., Zhang, Y. H., Lin, Y., Xue, L., Sun, T. L., Liu, X. G., Shao, M., Jayne, J. T., and Worsnop, D. R.: Characterization of submicron aerosols at a rural site in Pearl River Delta of China using an Aerodyne HighResolution Aerosol Mass Spectrometer, Atmos. Chem. Phys., 11, 18651877, https://doi.org/10.5194/acp-11-1865-2011, 2011.

Kirchstetter, T. W., Novakov, T., and Hobbs, P. V.: Evidence that the spectral dependence of light absorption by aerosols is affected by organic carbon, J. Geophys. Res., 109, D21208, https://doi.org/10.1029/2004jd004999, 2004. 
Lack, D. A., and Cappa, C. D.: Impact of brown and clear carbon on light absorption enhancement, single scatter albedo and absorption wavelength dependence of black carbon, Atmos. Chem. Phys., 10, 4207-4220, https://doi.org/10.5194/acp-10-4207-2010, 2010.

Lack, D. A., Langridge, J. M., Bahreini, R., Cappa, C. D., Middlebrook, A. M., and Schwarz, J. P.: Brown carbon and internal mixing in biomass burning particles, Proc. Natl. Acad. Sci. U S A, 109, 14802-14807, https://doi.org/10.1073/pnas.1206575109, 2012.

Liu, P. F., Zhang, Y., and Martin, S. T.: Complex refractive indices of thin films of secondary organic materials by spectroscopic ellipsometry from 220 to 1200 nm, Environ. Sci. Technol., 47, 1359413601, https://doi.org/10.1021/es403411e, 2013.

Liu, P. F., N. Abdelmalki, H.-M. Hung, Y. Wang, W. H. Brune, and S. T. Martin,: Ultraviolet and visible complex refractive indices of secondary organic material produced by photooxidation of the aromatic compounds toluene and m-xylene, Atmos. Chem. Phys., 15, 1435-1446, https://doi.org/10.5194/acp-15-1435-2015, 2015.

Moosmüller, H., and Arnott, W.P.: Angular Truncation Errors in Integrating Nephelometry, Rev. Sci. Instrum. 74, 3492-3501, 2003.

Onasch, T.B., Massoli, P., Kebabian, P.L., Hills, F.B., Bacon, F.W., and Freedman, A.: Single Scattering Albedo Monitor for Airborne Particulates, Aerosol Sci. Technol. 49, 267-279, https://doi.org/10.1080/02786826.2015.1022248, 2015.

Saleh, R., Marks, M., Heo, J., Adams, P. J., Donahue, N. M., and Robinson, A. L.: Contribution of brown carbon and lensing to the direct radiative effect of carbonaceous aerosols from biomass and biofuel burning emissions, J. Geophys. Res. Atmos., 120, 10285-10296, https://doi.org/10.1002/2015JD023697, 2015.

Sumlin, B. J., Pandey, A., Walker, M. J., Pattison, R. S., Williams, B. J., and Chakrabarty, R. K.: Atmospheric photooxidation diminishes light absorption by primary brown carbon aerosol from biomass burning, Environ. Sci. Tech. Lett., 4, 540-545, https://doi.org/10.1021/acs.estlett.7b00393, 2017.

Varma, R., Moosmüller, H., and Arnott, W. P.: Toward an ideal integrating nephelometer, Opt. Lett., 28, 1007-1009, https://doi.org/10.1063/1.1581355, 2003.

Wang, Q. Y., Huang, R.-J., Cao, J. J., Tie, X. X., Ni, H. Y., Zhou, Y. Q., Han, Y. M., Hu, T. F., Zhu, C. S., Feng, T., Li, N., and Li, J. D.: Black carbon aerosol in winter northeastern Qinghai-Tibetan Plateau, China: the source, mixing state and optical property, Atmos. Chem. Phys., 15, 1305913069, https://doi.org/10.5194/acp-15-13059-2015, 2015.

Wu, C., Wu, D., and Yu, J. Z.: Quantifying black carbon light absorption enhancement with a novel statistical approach, Atmos. Chem. Phys., 18, 289-309, https://doi.org/10.5194/acp-18-289-2018, 2018.

Wu, Y., Wang, X., Tao, J., Huang, R., Tian, P., Cao, J., Zhang, L., Ho, K.-F., Han, Z., and Zhang, R.: Size distribution and source of black carbon aerosol in urban Beijing during winter haze episodes, Atmos. Chem. Phys., 17, 7965-7975, https://doi.org/10.5194/acp-17-7965-2017, 2017.

Zhao, W., Xu, X., Dong, M., Chen, W., Gu, X., Hu, C., Huang, Y., Gao, X., Huang, W., and Zhang, W.: Development of a cavity-enhanced aerosol albedometer, Atmos. Meas. Tech., 7, 2551-2566, https://doi.org/10.5194/amt-7-2551-2014, 2014. 